\title{
VIRGÍLIO. Geórgicas I. Organização de Matheus Trevizam. Traduções de António Feliciano de Castilho e Matheus Trevizam. Belo Horizonte: Editora UFMG, 2013.93 p.
}

Thiago César Viana Lopes Saltarelli

Universidade Federal de Uberlândia (UFU), Uberlândia, Minas Gerais, Brasil saltarelli@outlook.com

To prefácio que abre o livro organizado por Matheus Trevizam, Paulo Sérgio de Vasconcellos constata que

“as Geórgicas, muitas vezes consideradas a obra-prima de Virgílio e, até mesmo, o cume da poesia latina, são, hoje em dia, no mundo todo, o poema virgiliano menos lido pelos não-especialistas". Diante desse quadro, é com contentamento que se deve receber esse mais recente trabalho sobre as Geórgicas. O livro está organizado em seis seções: abre-se com o já mencionado prefácio de Paulo Sérgio de Vasconcellos, professor de língua e literatura latinas da Unicamp, ao qual se segue um breve estudo das Geórgicas de autoria de Matheus Trevizam, professor de língua e literatura latinas da UFMG e organizador do livro; após o estudo, apresentam-se, dispostos em páginas paralelas, o texto original latino do livro I das Geórgicas e a tradução em prosa realizada por Trevizam; a partir daí, inicia-se a seção concernente ao poeta oitocentista português António Feliciano de Castilho: primeiramente, há um comentário sobre a sua tradução do poema de Virgílio, de autoria de Tereza Virgínia Ribeiro Barbosa, professora de língua e literatura gregas da UFMG; e, finalmente, a tradução em versos do livro I das Geórgicas empreendida por Castilho.

No que toca ao relativo insucesso da obra nos dias de hoje, Vasconcellos credita-o à ingratidão de um tema em princípio avesso à poesia - os trabalhos do campo. De nossa parte, aventamos ainda que o gênero do poema põe-no numa situação problemática para sua prévia identificação e classificação pelo leitor comum. Entre o lirismo das Éclogas e o épos da Eneida, há esse terceiro gênero (que, no caso, não se trata do dramático), proscrito pela dóxa da moderna teoria literária revisora de Aristóteles, e por isso mesmo furtivo às classificações. Ora, justamente a questão do gênero do poema - classificado então como 
didático a partir do estudo de preceitos retórico-poéticos helenísticos e latinos, portanto não anacrônicos — não escapa ao olhar minucioso de Trevizam em seu estudo da obra. Um de seus pontos altos encontra-se na identificação das afiliações genéricas das Geórgicas, no que se destacam o Hesíodo de Os trabalhos e os dias como fonte primeira, bem como, entre outros, Arato, Teofrasto, Lucrécio e eminentemente Varrão de Reate, com seu tratado De re rustica. Da poética alexandrina, Virgílio toma o gosto pelo esmero construtivo em menor escala, de que é índice o epýllion de Orfeu e Aristeu inserido no final da obra. Por essa razão, o poema didático foi muitas vezes considerado como uma versão menor da épica, ou como portador de um épos, embora não heroico.

E propriamente pela rede de emulações que Virgílio revela sua genialidade. Afinal, seguindo a preceptiva poética coetânea, imita as autoridades de cada gênero, mas nunca de maneira servil, senão para com elas medir-se e para buscar superá-las. Nesse sentido, Trevizam destaca a habilidade do mantuano para a pintura de panoramas evocativos da vida campesina itálica. As Geórgicas, assim, apresentar-se-iam como dípticos, harmonizando os tons pessimistas dos livros ímpares, e os otimistas dos livros pares. O proêmio do livro I e o "selo" ou sphragís no fim do livro IV encapsulam o corpo dos preceitos nestes painéis bem delineados.

E importante salientar, contudo, o caráter não realista dessa "pintura". Enquanto artefato ficcional, produto de uma poíesis mimética, o poema virgiliano não se quer espelho da realidade, figuração verídica da empiria. Antes, obedece a preceitos retóricos de gênero que regulam e prescrevem sua configuração, sua linguagem, seu estilo. Assim, por exemplo, como demonstra Trevizam, há uma ausência voluntária de burros e porcos no conjunto dos animais tratados nas Geórgicas, apesar de, segundo estudiosos da alimentação e da vida rural romana, os burros terem sido de capital importância para o transporte de cargas pesadas naquele universo, como os porcos o foram para a alimentação dos camponeses. Ocorre que esses animais, no que concerne às convenções retóricas de gênero, estavam associados ao cômico e ao ridículo, uma vez que podiam simbolizar, respectivamente, a falta de inteligência e a glutoneria. Logo, não poderiam estar presentes numa obra de gênero sério. Sua ausência, portanto, não deixa dúvidas quanto ao compromisso de Virgílio com as convenções retóricas, e não com a representação da realidade empírica da vida campestre itálica.

É nesse sentido, por fim, que ganha destaque o comentário de Trevizam sobre a encenação das personae poéticas no gênero didático 
e especificamente nas Geórgicas. Ele nos lembra de que o poema não é expressão subjetivista de um eu empírico, construindo-se, antes, como a enunciação fictícia de um eu não-substancial que se encena retoricamente como magister agricola. Similarmente, Virgílio, poeta urbanus, também enuncia retoricamente um leitor ideal, espécie de rusticus discipulus. Entretanto, como destaca Trevizam, pelo fato de o fingido "mestre" de agricultura não se aprofundar em todas as cruezas da lida campesina, a urbanitas do poema é preservada, garantindo assim que o público urbano real do poema não seja acometido pelo choque, pelo tédio ou pela sensação de inadaptabilidade da matéria à poesia.

Finalmente, vale ressaltar a felicidade que é dispor das duas traduções - a de Trevizam e a de Castilho — do livro I das Geórgicas, pois abrem-se ao leitor duas possibilidades, sem que uma tenha de necessariamente excluir a outra. Com a tradução de Matheus Trevizam, o leitor, sobretudo aquele versado na língua latina, tem o privilégio de acompanhar original e tradução como que simultaneamente - inclusive por sua disposição física em páginas paralelas — sendo guiado e iluminado na leitura do original pela tradução extremamente fiel, correta e literal do texto virgiliano. Com a tradução de Castilho, por outro lado, dá-se ao leitor a possibilidade de fruir um texto poético (no sentido atual de ser composto em versos), mesmo se o tradutor houver tido a necessidade de abandonar os recursos musicais da poesia latina e buscar os artifícios métricos, rítmicos e rímicos próprios da língua portuguesa, como ao transpor o hexâmetro latino para o alexandrino português. Em suma, os leitores ganham, com esse trabalho, um livro ideal no que tange à publicação de traduções de poemas gregos e latinos: podem ler o texto original; podem ler uma tradução mais literal, que contribui para iluminar passagens mais obscuras do original; e podem ler um trabalho de tradução poética da língua antiga para a língua portuguesa, na qual os recursos poéticos têm de ser adaptados da língua de partida para a língua de destino. 
